\title{
Waste Analysis Using Lean Manufacturing in the Film Production Process Step 2 Ulama
}

\author{
$1^{\text {st }}$ Wahyu Sidiq Saputra, $2^{\text {nd }}$ Muhammad Ridwan Andi Purnomo \\ ${ }^{1}$ Departemen Teknik Industri, Fakultas Teknik dan Rekayasa, Universitas Selamat Sri \\ ${ }^{2}$ Departemen Teknik Industri, Fakultas Teknik Industri, Universitas Islam Indonesia \\ ${ }^{1}$ wasidsap@gmail.com, ${ }^{2}$ ridwan_ie@uii.ac.id
}

\begin{abstract}
The film Footsteps 2 Ulama produced by LSBO Muhammadiyah in collaboration with Ponpes Tebuireng Jombang is a semi-documentary film that tells the journey of Kyai Ahmad Dahlan and Kyai Hasyim Asy'ari. At the time of the production of the film Jejak step 2 Ulama in its implementation there were several problems such as delayed production schedules, human resources that were not as needed, scheduling errors, and also production defects in several scenes so that they had to be re-take or it could be said to be re-production to get maximum results, where these problems tend to result in waste or waste. Therefore, a study was conducted to analyze what kind of waste occurs and the most dominant using a lean approach. Based on the results of the study, it was found that waste waiting is the most dominant waste with a weight of $27.11 \%$, then followed by waste over production and excess processing with the same weight of $20.33 \%$, waste defect $13.55 \%$, waste transportation $11.86 \%$, motion $5.08 \%$ and inventory $1.69 \%$. From the mapping using process activity mapping, a total of 32 types of activities were obtained, of which 12 were value added activities with a percentage of 50.36\%, then 9 of them were necessary non-value added activities with a percentage of $13.13 \%$, and 11 activities included in the non-value category. added with a percentage of $26.49 \%$.
\end{abstract}

Keywords: Lean manufacturing, Value stream mapping, Waste, 2 ulama's footsteps, Fishbone

\section{INTRODUCTION}

When the film Jejak Step 2 Ulama was produced, the location was set in several areas, including Kediri, Jombang, Madura, and the Special Region of Yogyakarta. At the time of the production of the film Jejak step 2 Ulama in its implementation there were several problems such as the delay in the production schedule, human resources that were not as needed, scheduling errors, and also production defects in several scenes so that it had to be re-take or it could be said to be re-production to get maximum result. If these problems are not immediately addressed, it will cause a lot of losses, where losses can occur in the form of money, energy, time or in other forms, which of course things like this in the industrial world are highly avoided and must be minimized or even eliminated.

The concept of lean manufacturing is considered to be the most appropriate alternative to solve the problems that occur, as for the reason why you should implement lean manufacturing, namely by implementing lean manufacturing it can streamline processes in all parts, eliminate waste or waste, build team commitment, and make work sustainable. namely continuous improvement in every process carried out. One of the tools in lean is value stream mapping (VSM), where the tool can provide opportunities to make improvements and reduce waste. In practice VSM is made in the form of a graph in the form of a flowchart and is used to analyze and design the flow of materials and information needed to provide products or services to customers. With the use of VSM, it is hoped that the points that cause waste will be identified, and the causes of the waste that occur are analyzed so that solutions can be given for improvement.

Therefore, on this occasion the author will conduct a study that analyzes what wastes occur in the production process of the film Jejak Step 2 Ulama using lean manufacturing, which later is expected to have an output solution for the evaluation of the film production team, of course. As for what distinguishes this research from previous research, it can be said that the application of lean service for waste analysis in the creative industry sector such as this film has never been done.

Based on the formulation of the problem above, it can be obtained that the research objectives to be achieved are as follows:

a. Describe the production process of the film Jejak Step 2 Ulama in value stream mapping (VSM) and then identify the waste that occurs in the production process of the film Jejak Step 2 Ulama and analyze the cause.

b. Knowing the activities that include value added, non value added and necessary non value added in the film production process of the Ulama's Footsteps 2 and provide recommendations for improvements that can be used for the next film production.

The research carried out has the following benefits:

a. Knowing the flow of information, values, and physical activities that occur in the production process of the film Jejak Step 2 Ulama.

b. Knowing the waste or waste that occurs in the production process of the film Jejak Step 2 Ulama.

c. Knowing the causes of the emergence of waste that occurs in the production process of the film Jejak Step 2 Ulama.

d. Can be used as literature and additional for further researchers.

Lean principles are derived from the Toyota management system that has been developed. Toyota's management system aims to improve quality, minimize costs and delivery accuracy by streamlining the flow of the production process and eliminating waste. Lean is a 
Peer Reviewed - International Journal

Vol : Vol. 02, Issue 03, August 2021

e-ISSN : 2745-9659

https://ijcis.net/index.php/ijcis/index

set of tools and methods designed to eliminate waste, reduce waiting time, improve performance, and reduce costs. The goal of Lean is to eliminate all process waste and maximize process efficiency.

Lean can be defined as a systemic and systematic approach to identify and eliminate waste or non-value adding activities through radical continuous improvement by flowing products (materials, work in process, output) and information using a pull system and internal and external customers to pursue excellence and perfection.

Waste is all activities that do not add value, waste or youth (in Japanese) is any activity that does not add value that customers do not want to pay for. Ohno, like Womack and Jones, grouped waste into 7 categories (Ohno, 1988; Womack and Jones, 2003) stating the 7 main wastes in the Toyota Production System, namely:
a. Waste of over production
b. Waste of time on hand(waiting)
c. Waste in transportation
d. Waste of processing it self
e. Waste of stock on hand(inventory)
$f$. Waste of movement
g. Waste of making defective products

\section{RESEARCH METHODS}

The object of this research is the production process of the film "Jejak Step 2 Ulama", where this film is the result of negotiations and collaboration between the Muhammadiyah Arts, Culture and Sports Institute (LSBO) under the auspices of the chairman of the Muhammadiyah central leadership Mr. Haedar Nasir and the Tebuireng Islamic Boarding School under the auspices of Gus Solah.

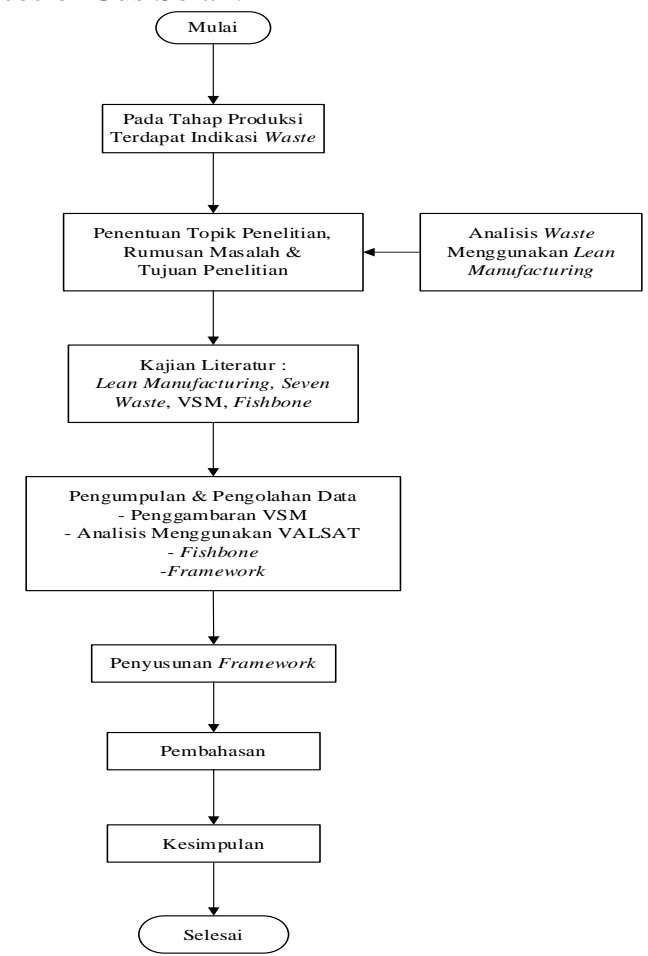

Figure 1. Research Flowchart

\section{RESULTS AND DISCUSSION}

\section{Data Collection And Processing}

a. Value Stream Mapping

From the observation, it was found that the production scheduling data for the film "Jejak Step 2 Ulama" was found, namely that it was found that the targeted production process would be completed within 22 days. But in reality, it is undeniable that unexpected and unexpected things happened when the production process took place in the field, so inevitably there had to be an additional production schedule to complete the production, which was for 8 days.

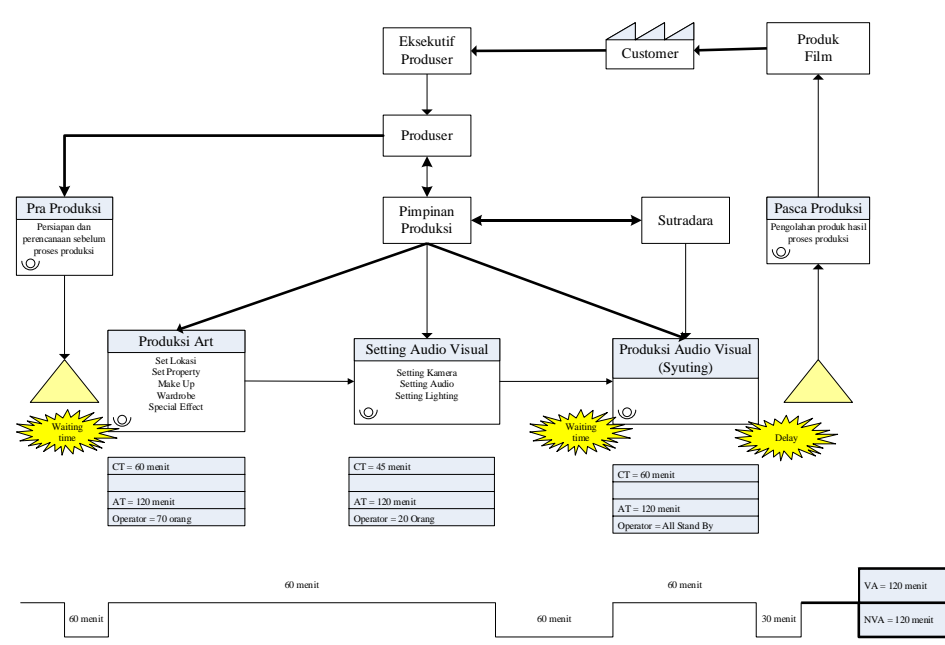

Figure 2. Current State Value Stream Mapping

Based on the analysis of the current state value stream mapping that has been made, it can be said that the waste that occurs a lot during the production process is waiting. In addition, as a result of the problems that occurred, it caused quite a massive mess, including the production schedule that had been set so it was quite chaotic from the first day of production. Based on observations made in the field, it is quite striking that the predetermined production schedule does not run smoothly, namely because of the human factor.

\section{b. Process Cycle Eficiency}

According to (Gaspersz, 2008), process cycle efficiency is one of the key performance indicators (KPIs) of the current value stream process (CSVSM). The following is the formula used in PCE calculations:

$$
\text { Process Cycle Efficiency }=\frac{\text { Value Added Time }}{\text { Total Lead Time }}
$$

The PCE calculations carried out in the production process of one scene in the film Jejak Step 2 Ulama are as follows:

$$
P C E=\frac{120 \text { minutes }}{240 \text { minutes }} \times 100 \%=50 \%
$$


Peer Reviewed - International Journal

Vol : Vol. 02, Issue 03, August 2021

e-ISSN : 2745-9659

https://ijcis.net/index.php/ijcis/index

After the calculation, it can be seen that the PCE value obtained from CSVSM in the production process of the film scene in the footsteps of the Ulama is $50 \%$. From this value, it can be said that the opportunity for increasing process cycle efficiency is still very large.

\section{c. Waste Identification}

The following are the results of observations made at the location of the film production Jejak Step 2 Ulama, where researchers found various wastes that occurred during the production process. The following is a table of the waste that has occurred which has been categorized according to its type.

Table 1. Waste Identification

\begin{tabular}{|c|c|}
\hline \multicolumn{2}{|r|}{ Waste Identification } \\
\hline Category & Waste \\
\hline Waiting & 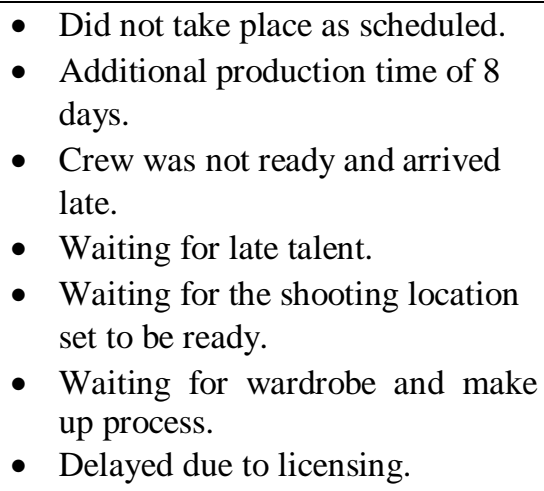 \\
\hline Defect & $\begin{array}{l}\text { - Often cracks occur during } \\
\text { shooting. } \\
\text { - There is a repetition of the } \\
\text { production process. }\end{array}$ \\
\hline Transportation & $\begin{array}{l}\text { - Often cracks occur during } \\
\text { shooting. } \\
\text { - There is a repetition of the } \\
\text { production process. }\end{array}$ \\
\hline $\begin{array}{l}\text { Over } \\
\text { Production }\end{array}$ & $\begin{array}{l}\text { - Some scenes were deleted because } \\
\text { they were too long. } \\
\text { - Production quantity is too much. } \\
\text { - A lot of trimming of scene parts is } \\
\text { done. }\end{array}$ \\
\hline Motion & $\begin{array}{l}\text { - Layout between parts is less } \\
\text { efficient, causing waste in motion. }\end{array}$ \\
\hline Over Process & $\begin{array}{l}\text { - Excessive daily working hours. } \\
\text { - Lasts until late at night. } \\
\text { - Crew and talent are overworked. } \\
\text { - Too chasing targets but not } \\
\text { balanced with integrity. }\end{array}$ \\
\hline Inventory & $\begin{array}{l}\text { - Some of the items brought are not } \\
\text { used, causing waste infentory. }\end{array}$ \\
\hline
\end{tabular}

d. Process Activity Mapping

By using process activity mapping or commonly abbreviated as PAM which is one of the tools in VALSAT, with these tools will be described every existing activity so that it can be seen the relationship between each existing process and identify what types of activities exist in a process whether the process is included in the types of activities VA (value added), NVA (non value added) and NNVA (necessary non value added). The following is the process involved in the production of the film Jejak Step 2 Ulama which has been entered into the PAM table.

Based on the results of the PAM film production process Step 2 Ulama contained in table 4.5 shows that in each production of one scene there are thirty-two activities, of which 12 activities are included in the value added category, then 9 activities are included in the necessary non-value added category and 11 activities are in the non-value added category. value added. The following are the types of activities that fall into the VA, NVA, and NNVA categories:

Table 2. Grouping Types of Activities

\begin{tabular}{|c|c|c|c|}
\hline \multirow{2}{*}{ No } & \multicolumn{3}{|c|}{ Type of activity } \\
\hline & VA & NNVA & NVA \\
\hline 1 & $\begin{array}{l}\text { Location set } \\
\text { cleaning }\end{array}$ & $\begin{array}{l}\text { Location } \\
\text { team } \\
\text { briefing }\end{array}$ & $\begin{array}{l}\text { Completeness } \\
\text { and readiness of } \\
\text { the location and } \\
\text { art set team. }\end{array}$ \\
\hline 2 & $\begin{array}{l}\text { Setting the } \\
\text { location for } \\
\text { production }\end{array}$ & $\begin{array}{l}\text { Briefing } \\
\text { team } \\
\text { property }\end{array}$ & $\begin{array}{l}\text { Prepare the } \\
\text { necessary tools } \\
\text { and materials }\end{array}$ \\
\hline 3 & $\begin{array}{l}\text { Install property } \\
\text { in set location }\end{array}$ & $\begin{array}{l}\text { Briefing } \\
\text { team make } \\
\text { up }\end{array}$ & $\begin{array}{l}\text { Prepare the } \\
\text { required } \\
\text { properties }\end{array}$ \\
\hline 4 & $\begin{array}{l}\text { Talent make- } \\
\text { up process }\end{array}$ & $\begin{array}{l}\text { Briefing } \\
\text { team } \\
\text { wardrobe }\end{array}$ & $\begin{array}{l}\text { Prepare make-up } \\
\text { tools }\end{array}$ \\
\hline 5 & $\begin{array}{l}\text { Applying } \\
\text { wardrobe to } \\
\text { talent as } \\
\text { needed }\end{array}$ & $\begin{array}{l}\text { Briefing } \\
\text { team special } \\
\text { effect }\end{array}$ & $\begin{array}{l}\text { Prepare } \\
\text { wardrobe } \\
\text { equipment }\end{array}$ \\
\hline 6 & $\begin{array}{l}\text { Application of } \\
\text { special effects } \\
\text { to set locations }\end{array}$ & $\begin{array}{l}\text { Camera team } \\
\text { briefing for } \\
\text { preparation }\end{array}$ & $\begin{array}{l}\text { Prepare special } \\
\text { effects needs }\end{array}$ \\
\hline 7 & $\begin{array}{l}\text { Application of } \\
\text { the camera } \\
\text { according to } \\
\text { the required } \\
\text { position }\end{array}$ & $\begin{array}{l}\text { Briefing } \\
\text { team audio }\end{array}$ & $\begin{array}{l}\text { Preparing } \\
\text { camera settings }\end{array}$ \\
\hline 8 & $\begin{array}{l}\text { Application of } \\
\text { audio tools to } \\
\text { location \& } \\
\text { talent sets }\end{array}$ & $\begin{array}{l}\text { Briefing } \\
\text { team lighting }\end{array}$ & $\begin{array}{l}\text { Prepare the } \\
\text { necessary audio } \\
\text { set tools }\end{array}$ \\
\hline 9 & $\begin{array}{l}\text { Installing } \\
\text { lighting at the } \\
\text { location set }\end{array}$ & $\begin{array}{l}\text { Conditioning } \\
\text { the entire } \\
\text { crew of each } \\
\text { section to be } \\
\text { ready for } \\
\text { shooting. }\end{array}$ & $\begin{array}{l}\text { Prepare lighting } \\
\text { equipment }\end{array}$ \\
\hline 10 & $\begin{array}{l}\text { The process of } \\
\text { blocking talent, }\end{array}$ & & $\begin{array}{l}\text { Waiting for the } \\
\text { set of shooting }\end{array}$ \\
\hline
\end{tabular}


International Journal of Computer and Information System (IJCIS)

Peer Reviewed - International Journal

Vol : Vol. 02, Issue 03, August 2021

e-ISSN : 2745-9659

https://ijcis.net/index.php/ijcis/index

\begin{tabular}{lll}
\hline & property and & locations to be \\
& lighting & ready for use. \\
11 & Audio and & The lock \\
& video capture & decision process \\
& (Shooting) & results take \\
12 & Retake process & \\
\hline
\end{tabular}

Table 3. Total activity time

\begin{tabular}{ccc}
\hline $\begin{array}{c}\text { Activity } \\
\text { Category }\end{array}$ & $\begin{array}{c}\text { Time } \\
\text { (minutes) }\end{array}$ & Percentage \\
\hline VA & 345 & $50,36 \%$ \\
NNVA & 90 & $13,13 \%$ \\
NVA & 250 & $26,49 \%$ \\
Total & 685 & $100 \%$ \\
\hline
\end{tabular}

Table 4. Number of each type of activity

\begin{tabular}{ccc}
\hline Activity Category & Amount & Percentage \\
\hline Operation & 12 & $37,5 \%$ \\
Transportation & 8 & $25 \%$ \\
Inspection & 9 & $28,12 \%$ \\
Storage & 0 & $0 \%$ \\
Delay & 3 & $9,37 \%$ \\
Total & 32 & $100 \%$ \\
\hline
\end{tabular}

Table 5. Total time for each type of activity

\begin{tabular}{ccc}
\hline Activity Category & Time & Percentage \\
\hline Operation & 350 & $51,09 \%$ \\
Transportation & 95 & $13,86 \%$ \\
Inspection & 90 & $13,13 \%$ \\
Storage & 0 & $0 \%$ \\
Delay & 150 & $21,89 \%$ \\
Total & 685 & $100 \%$ \\
\hline
\end{tabular}

e. Waste Analysis Using Fishbone

Furthermore, from the results of the previous borda analysis together with the results of observations and direct observations in the field, it can be seen that the most dominant waste occurs in the production process of the film Jejak Step 2 Ulama, namely waste waiting, then followed by waste over production and over processing. Then the defect waste is in fourth place, followed by transportation in fifth, then motion and inventory waste is in 5th and 6th place. Therefore, waste with a high level of dominance will be parsed using a fishbone diagram to find out the cause, as for the results of fishbone diagram is as follows:

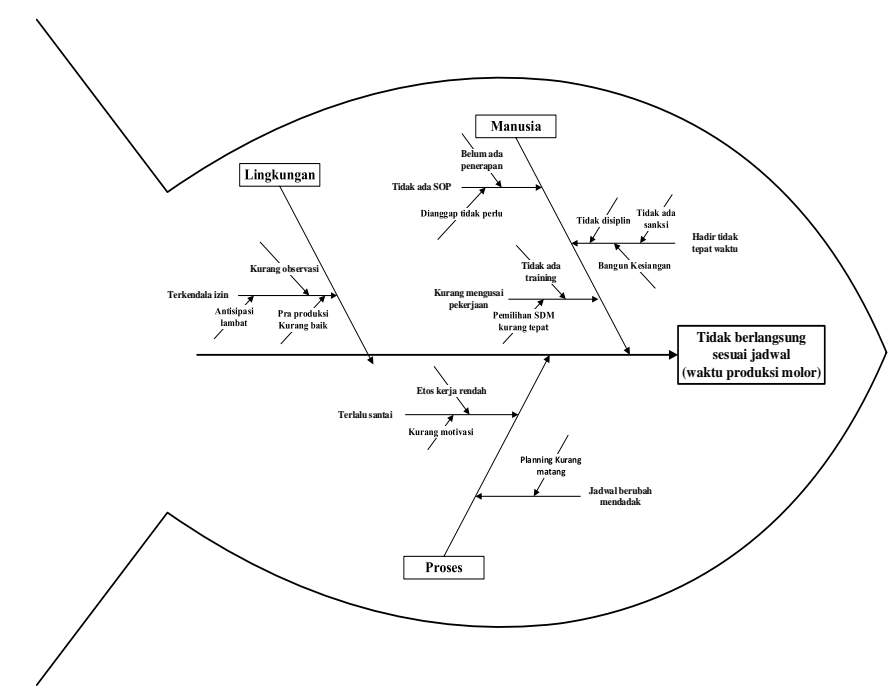

Figure 3. Fishbone diagram of the process of waste waiting (1)

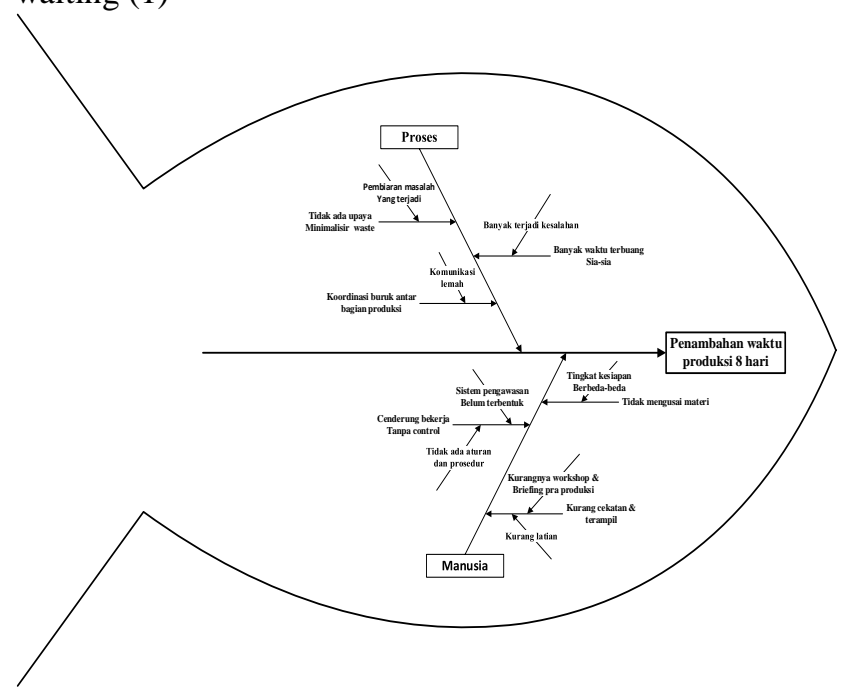

Figure 4. Fishbone diagram of the process of waste waiting (2)

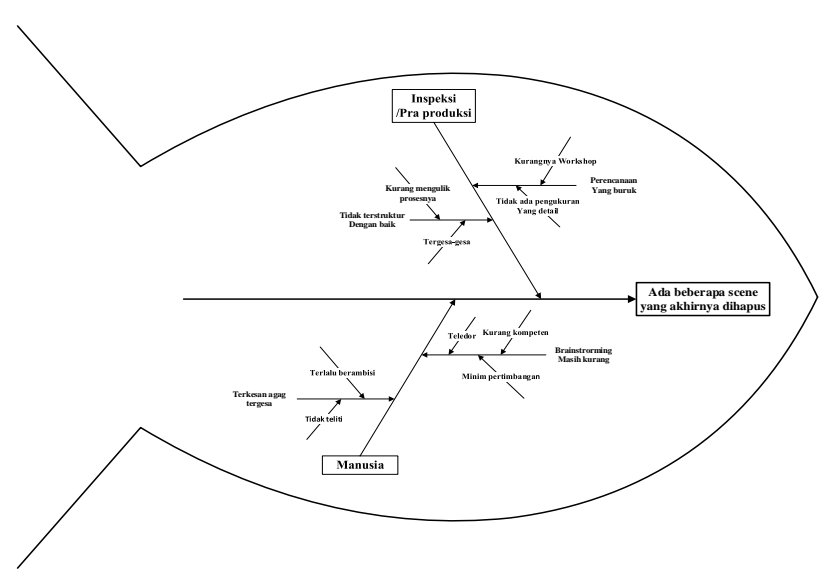

Figure 5. Fishbone diagram of the process of over production 


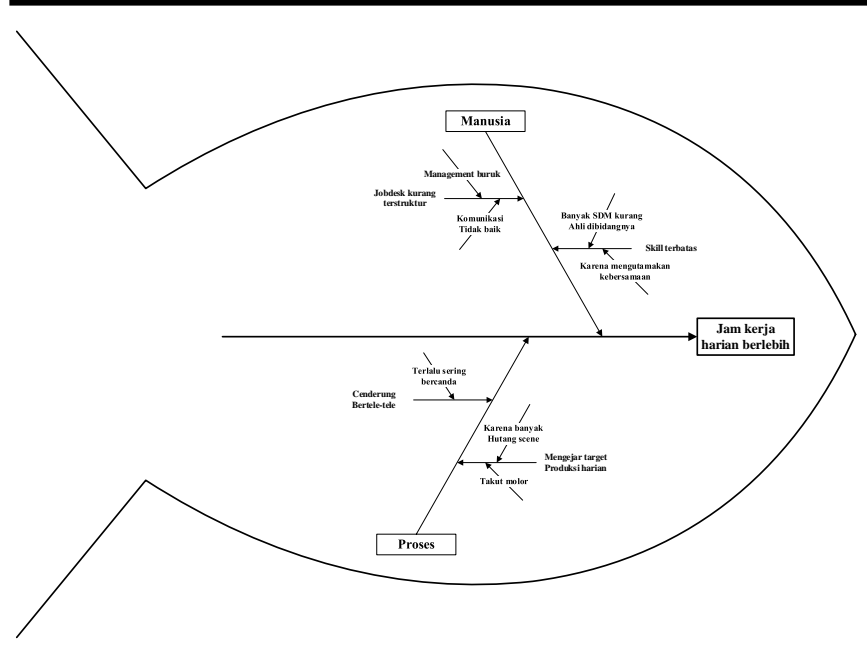

Figure 6. Fishbone diagram of the process of over processing

\section{CONCLUSION}

The conclusions obtained from this study include the following:

a. Based on the research that has been done, from the results of the value stream mapping there are 3 kaizenburst points where there is waste waiting which is quite long and very detrimental to the production process, it is also concluded that based on the analysis with the borda concept, measurement of waste weighting is carried out, where waste waiting is the most dominant waste. with a weight of $27.11 \%$, followed by waste over production and excess processing with the same weight of $20.33 \%$, defect waste $13.55 \%$, transportation waste $11.86 \%$, motion $5.08 \%$ and inventory $1.69 \%$. Then from the seven wastes, the four most dominant wastes were analyzed using a fishbone diagram, the most dominant causal factors were human factors and process factors.

b. From the research that has been done, it can be seen that the conclusions from the analysis using one of the value stream analysis tools, namely process activity mapping, there are a total of 32 types of activities, of which 12 are value added activities with a percentage of $50.36 \%$, then 9 of them are necessary non-value activities. added with a percentage of $13.13 \%$, and 11 activities that fall into the category of non-value added with a percentage of $26.49 \%$.

The suggestions in the research, as follows:

a. It is advisable to do research with similar objects but in more detail from the pre-production process to the post-production process in order to get more detailed and comprehensive results.

b. The film production team of Jejak Step 2 Ulama should conduct comparative studies with film producers who have implemented a good supervision control system and standard operating procedures in film production.

c. Because the causes of waste waiting are mostly human factors, it is recommended that for the next production process, the selection of workers for the production team is more selective and strict.

\section{REFERENCES}

[1.] Abu, F., Gholami, H., Saman, M.Z.S., Zakuan, N., \& Streimikiene, D. (2019). The implementation of lean manufacturing in the furniture industri : A review and analysis on the motives, barriers, challenge and the applications. Juournal of Cleaner Production, 234, 660-680.

[2.] Covey, Stephen,. Seven Habits for Highly Effective People, (Budijanto, Penerjemah), Jakarta: Binarupa Aksara: 1997.

[3.] Daonil. (2012). Eliminasi Waste pada Lini Produksi Machining Cast Wheel dengan Menggunakan Metode WAM dan VALSAT. Fakultas Teknik, Universitas Indonesia.

[4.] Gaspersz, V. (2008). The Executive Guide to Implementing Lean Six Sigma : Strategi Dramatis Reduksi Cacat/Kesalahan, Biaya, Inventory, dan Lead Time dalam waktu kurang dari 6 Bulan. Jakarta: PT Gramedia Pustaka Utama.

[5.] Heider, Karl. (1991). Indonesian Cinema: National Culture on Screen. Honolulu: University of Hawaii Press.

[6.] Hines,P. \& Taylor, D. (2000). Going Lean. Cardiff, UK: Lean Enterprise Research Centre Cardiff Business School Aberconway Building Colum Drive.

[7.] Liker, Jefrey K. The Toyota Way, New York : McGraw-Hill Co.Inc, 2004.

[8.] Lovelle,J. 2001. Mapping the Value Stream. ProQuest, pp. Vol 33, Iss 2, pg 26.

[9.] Nugroho, Garin \& Dyba Herlina. (2015). Krisis dan Paradoks Film Indonesia. Jakarta: PT. Kompas Media Nusantara.

[10.] Octaviany, I.N., Yanuar, A.A., \& Rendra, M. (2017).Penerapan lean manufacturing untuk meminimasi waste waiting pada proses produksi hanger sample di CV.ABC offset. Jurnal Rekayasa Sistem \& Industri, 4, 76-83.

[11.] Santoso, L. P., Muqorobin, M., \& Fatkhurrochman, F. (2020). Online Analysis System of Application of Partners for Land Asrocument Officers of Sukoharjo District. International Journal of Computer and Information System (IJCIS), 1(3), 59-61. 